\title{
Kristologien i Grundtvigs salmer
}

\author{
Af Jakob Flфe Nielsen
}

Målet med dette foredrag er en samlet betragtning af vigtige måder at tale om Kristus på i Grundtvigs salmer og en sammenkædning af disse udsagn om Kristus til et helhedsbillede af, hvem Kristus er, og hvad han gør.

Før jeg kan tage fat på selve emnet er der to afklaringer, vi må foretage. Det drejer sig om ordene "salmer" og "kristologi". Ordet salme definerer jeg meget bredt, så bredt at det i denne sammenhæng dækker over den del af Grundtvigs digtning, der er samlet i værket: Grundtvigs Sangværk I-V. Hvad angår begrebet kristologi, vil jeg ligeledes i første omgang foretage en meget vid afgrænsning og slet og ret forstå begrebet som "udsagn om Kristus", i anden omgang vil jeg så mene, at udsagnene om Kristus i Sangværket forbinder sig med hverandre til en sammenhængende lære om Kristus. Man kunne ganske vist med Grundtvigs bundethed til Apostolicum in mente indvende, at læren om Kristus kan man finde i 2. trosartikel, og hvad der er derudover er af det onde, men det ville have den ejendommelige konsekvens, at nogle af de hyppigst forekommende og mest gennemreflekterede udsagn om Kristus hos Grundtvig, nemlig Kristus som "ordet" og "Kristus som håbet om herlighed" ville falde udenfor. Ser man nøjere efter, falder Grundtvigs tale om Kristus til dels uden for, hvad man sædvanligt forstår som kristologiens område uden dog af den grund at slippe forbindelsen med den klassiske kristologi.

Jeg vil gerne begynde beskæftigelsen med selve emnet for foredraget med at opridse nogle overordnede særkendetegn ved den måde Grundtvig taler om Kristus på. For det første bruger han hele det klassisk kristologiske begrebsapparat. Han anvender tanken om præexistensen, hvor han taler om Kristi meddelagtighed i skabelsen, og hvor Faderen og Sønnen sammen diskuterer inkarnationen før den sættes i værk (Grundtvigs Sangværk bd. IV nr. $231 \mathrm{og}$ bd. I nr. 206. (Fremover henvises til dette værk med romertal for bind og arabertal for nummer uden nærmere angivelse af værket.)) Inkarnationen spiller en stor rolle i salmerne $i$ alle faser fra Jesu undfangelse til hans død. Nedfarten til 
dødsriget tages op og anvendes i flere sammenhænge ligesom også himmelfart og Kristi tilbagevenden til Faderens højre hånd. Denne klassiske nedstignings-opstigningsstruktur, som vi i koncentreret form kender fra Filipperbrevet 2.6-11, er efter mine skøn den grundlæggende kristologiske form hos Grundtvig. Alligevel får strukturen hos ham en helt særlig udformning, fordi den kombineres med Grundtvigs tanke om Kristi tilstedeværelse i sit ord $\mathrm{i}$ verden efter himmelfarten og Grundtvigs tanke om Kristi tilstedeværelse som Herlighedens Håb i troende døbte og Kristi enhed med menigheden ved nadveren. Dette medfører at Kristi bevægelse tilbage fra fornedrelse til ophøjelse i Guds herlighed har et trefoldigt forløb: dels foregik opstigningen, da Jesus for til himmels. Dels er opstigningen en bevægelse, Kristus ad sære, slyngede veje udfører i historien, vandrende i ordet gennem de syv menigheder, og endelig er opstigningen en håbets vækst til guddomsherlighed og -bevidsthed $\mathrm{i}$ de enkelte døbte. Kristi vandring gennem historien som Ordet vil jeg i denne sammenhæng kun behandle sporadisk for i stedet at koncentrere mig om sammenhængen mellem Grundtvigs udsagn om den inkarnerede Kristus og hans udsagn om Kristus, der i gudstjenesteordet formidler sig til den troende og lader sig genføde i ham som håbet om herlighed. Den kristusforståelse, der kommer til udtryk i de to titler: Kristus som Ordet og Kristus som Håbet, betyder, at Grundtvig i højere grad end så mange andre salmedigtere kan tale præcist om Kristi gerninger for os og hos os. Det hænger sammen med et andet særkendetegn ved den måde, Grundtvig taler om Kristus på: Grundtvig udnytter sine filosofiske og psykologiske erkendelser og sine personlige erfaringer fuldt ud, når han taler om Kristus. Når Grundtvig kalder Kristus for Ordet og Haabet, er det ikke bare fordi, der står sådan i hhv. Johannesevangeliet og Kolossenserbrevet, men det er fordi, den bibelske terminologi rammer, hvad Grundtvig selv har gennemtænkt og gennemlevet, og dette møde mellem den bibelske terminologi og Grundtvigs person, kommer der, som jeg skal forsøge at vise, noget meget frugtbart ud af.

Et tredje særkendetegn, jeg også gerne vil drage frem til indledning, er dette, at Grundtvigs udsagn om Kristus i salmerne bliver dybt solidariske med menneskelivet, som det trods ondskab og død leves i verden. Der findes ganske vist hos Grundtvig "far 
verden, far vel"-agtige udsagn, men de overdøves af "ved støvet hænger dog min sjæl"-udsagnene. I den sammenhæng kan man godt tale om skabelsesteologi, blot tror jeg, at det frem for at være et spørgsmål om lære eller anskuelse for Grundtvig drejer sig om lidenskab, om en ubændig lyst til at leve det liv, han nu en gang kun kender fra denne jord. Netop på grund af sin store kærlighed til livet i denne verden, kan Grundtvig ikke akceptere, at sandheden om livet skulle være, at det skal lide og opløses og forgå: livet skal være evigt! ellers er der ikke noget ved det. Det onde skal forsvinde, ellers er evigheden jo et mareridt. Og sådan mente Grundtvig ikke bare det var ham selv, der havde det. Tværtimod mener han, at det må være et grundtræk hos alle rigtige mennesker, at de på én gang oplever deres liv som herlige, fordi de er til, og samtidig som tragiske, fordi de er truede og skal høre op. Det er den netop skitserede forståelse af menneskelivet, der danner forudsætning og forståelsesbaggrund for kristologien. Menneskelivet skildres af Grundtvig i salmerne som det løsrevne gudsbillede: positivt viser gudbilledligheden sig som menneskets evne til at tale og dels $i$ sproget afbilde den sansede omverden $i$ ord, dels at udtrykke den indre individuelle verden $\mathrm{i}$ ord og gøre andre delagtige $\mathrm{i}$ den, og endelig i sproget at modtage den aldrig sete og aldrig oplevede virkelighed: Gud. Yderligere viser Guds afbillede sig i mennesket som dets bevidsthed om godt og ondt og sandt og løgn i samvittigheden og måske frem for alt i menneskets evne til at rumme og udfolde kærlighed. Men fordi gudbilledligheden $\mathrm{i}$ verden er løsrevet fra den virkelighed, den afbilder, ytrer den sig også negativt som afbilledets savn og længsel efter den virkelighed, det er revet løs fra, eller som en drøm eller et minde om en oprindelig lyksalighedstilstand. Jeg nævnte før, at den af faldet bestemte gudbilledlighed er forståelsesbaggrund for kristologien. Det skyldes at de to modstridende kræfter i mennesket: fald og gudbilledlighed danner hvv. behov og mulighed for at mennesket kan frelses. Behov er der for at mennesket frelses, fordi det er besat og behersket af en ond magt, der river det løs af tilhørsforholdet til Gud og i stedet overlader det til dets eget skøn. Og dette er katastrofalt, idet Grundtvig opfatter menneskehistorien som en opvækst og dannelse af mennesket frem mod en indsigt i skaberværkets sammenhænge, der skal komme til at svare til Guds egen indsigt (III 114.13), så når dette endnu 
ikke udvoksede væsen vil lade sit liv $\mathrm{i}$ verden forme og bestemme af sit barnespæde skøn, $m a ̊$ det gå galt (V 271.6-8). Men samtidig er den faldne gudbilledlighed menneskets mulighed for frelse: var der ikke noget af det oprindeligt gode, sande, skønne og ægte tilbage i mennesket, var der heller ikke noget at frelse (V 52.15).

Det vil være kendt, hvordan Grundtvig sammenfatter det gudbilledlige i mennesket i symbolet "hjertet": hjertet er dåret som faldent, og hjertet sukker, håber, længes og drømmer, fordi det er gudbilledligt. Samtidig er det nok også velkendt, hvordan Grundtvig opfatter hjertet som den kvindelige side af menneskets væsen. Når jeg drager disse ting frem, skyldes det, at Grundtvig opfatter Maria, Jesu mor, som hjertekvinden frem for nogen. Grundtvig har i "Der sad en Jomfru i Nazareth" (III 198) skildret hende som en kvinde der sidder og drømmer om Paradis og Israels heltetid ved sin væv, da Gabriel kommer og meddeler hende, at hun skal føde Guds søn. Digtet er spændende, fordi det viser kampen mellem fald og gudbilledlighed som en psykisk konflikt i mennesket. Marias første reaktion på englens komme er en gysende glæde. Men da englen fortæller, hvad der skal ske, får slangens magt overtaget $\mathrm{i}$ hende, og hun sætter sin egen forvildede tankegang ind overfor engleordet. Gabriel henviser til Helligånden, der skal komme over hende, og Guds Ord, som mægtede at lade hendes gamle slægtning Elisabeth blive gravid, og da sejrer det gudbilledlige hjerte i Maria over al sund skepsis: hun tager ordet til sig og undfanger Guds søn. Man kan betragte dette digt som en grundlæggende skildring af de møder mellem ord og tro, som vi skal se spiller en så væsentlig rolle $i$ Grundtvigs kristologi. Vi bemærker, at englens komme til Maria hensætter hende $\mathrm{i}$ en stærk uro, som når der pludselig $\mathrm{i}$ et menneske tales til noget længst glemt og fortrængt: det var det oprindelige, det af Gud skabte i Maria, der blev talt til, og som styrket af engleordet brød igennem sit fangenskab under hjernens dominans. Noget tilsvarende gør sig gældende, da rygtet om Jesu, Guds- og menneskesønnens, fødsel begynder at brede sig ved stjernens og englenes hjælp. Vi ser det $\mathrm{i}$ den tidlige udgave af Dejlig er den Himmel blaa (II 61), hvor den gamle stjernekigger bliver barneglad i sindet og kongen, som han fortæller det til, bliver hjertensglad over at høre, at det lys, der var talt om i den 
gamle spådom, nu var til stede. Og i digtet "Nat i Østen" (IV 161) optræder to hyrder, en ung og en gammel. Den unge har for nylig set den gravide Maria på gaden $i$ Bethlehem, omringet af gadedrenge og forkommen af kulde, sammen med Josef, davidsætlingen. Synet af det trøstesløse par i stamfaderens by får den unge til at udbryde:; "forældet Storhed! forlorent Haab!" for alle Biblens visioner og forjættelser modsiges af realiteterne: "Vinternatten er kold og mørk,/Og Livet øde som Ethams Ørk." Da farer den forjættelsestro, gamle Jonathan op og henviser med Jobsbogens ord til Guds uudgrundelige storhed og visdom, som han ser bekræftet af rygterne om den gamle Zacharias og hans englesyn i templet. Netop Bethlehem, siger han, peges der på i Skriften som nyskabelsens sted: kan hænde at parret, den unge hyrde havde fundet ynkeligt, i stedet er udgangspunkt for verdens frelse. Denne tro i vinternatten bekræfter englene med budskabet om Jesu fødsel.

Én ting er budskabet om Jesu fødsel. Men hvad med barnet selv? Er der ved den nyfødte Jesus noget særligt og underfuldt, der kan bekræfte englenes forkyndelse og biblens forjættelser om ham? I 1810 udgaven af "Dejlig er den Himmel blaa" (II 61) får vi til slut at vide, at vismændene genfinder stjernen, som de havde set $\mathrm{på} \mathrm{himlen} \mathrm{i}$ det spæde barns øjne, og det bliver for dem tegnet på, at de har fundet den sande Krist. Poetisk betragtet er det måske nok udmærket, fordi stjernen i øjet fortæller noget om himmelspejlingen i støvmennesket, men teologisk er løsningen ikke så heldig, fordi stjernen i barneøjet antyder, at der er huller og sprakker i Jesu menneskelighed, som hans guddommelighed kan skinne ud igennem, så Jesu menneskelighed ikke er ægte menneskelighed, men blot en slags dække over hans guddommelighed. I salmen "Himmerigets Poder smaa" (III 248), der i Grundtvigs forfatterskab er en slags efterklangsdigt til "Dejlig er den Himmel blaa", anskuer Grundtvig det spæde Jesusbarn på en helt anden måde. Her er barnet i krybben slet og ret, et spædbarn, der endnu hverken kan tale eller tænke. Alligevel fortæller dette spædbarn vismændene mere om himlen, end hele stjernevrimlen formår. Grunden får vi ikke direkte at vide, men jeg læser digtet sådan, at alene fordi han er et menneskebarn, fortæller Jesus om al tings mening og mål. Derfor omtales han også som et gudsbarn, der ligger i svøb. Selvfølgelig går dette på Guds søn, der er svøbt 
i krybben; men det går også på selve menneskelivet skabt til "at ligne sin Gud på det bedste/ og tale med ham som sin næste", det menneskeliv, der endnu kun er til stede som kim, som uudfoldet mulighed. Derfor hedder det også om Jesus i krybben:

"I Hans store Øine blaa

Himlens hele Klarhed laa,

Dunkel som en nyfødt Stjerne

Sjælen i den Lilles Hjerne

Vidste end ei af sig selv!"

I denne strofe antydes også den bevidsthed om sig selv, der skal komme til at skille Jesus fra alle andre: Jesus vokser op til at blive sig selv bevidst som Guds barn, vi andre vokser op til at blive os selv bevidste som selvberoende "jeg'er". Denne forskel i selvbevidsthed mellem Jesus og os andre, i hvem faldet endnu er en realitet, vil Grundtvig gøre synlig i sin måske nok ikke helt vellykkede sang "I Nazaret der var saa smukt" (II 64). Nøglen til forståelsen af denne Nazareth-idyl er str. 7 og 8, hvor det dels siges, at Jesus er bevidst om sit tilhørsforhold til Gud, dels at han villigt lader sig lede af Guds Ånd, der svæver over ham. Jesus er i sin menneskelighed karakteriseret ved at være åben og modtagelig over for Gud i Himlen. Tilsvarende hedder det om den tolvårige Jesus i templet i II 65:
"Letnem tilvisse og var Guds Søn,
Skiøndt dannet af Støv var hans Hjerne,
Kiærlighed mødte i Lys og Løn
Vidaabent det gyldne Muld-Hjerte."

Han spejler himlen, gør Jesus, derfor taler Grundtvig i forbindelse med ham også om blå himmel og blå skyer, hvor det $\mathrm{i}$ forbindelse med det faldne menneske hedder, at skyerne graane. Jesu ubrudte henvendthed mod Faderen i Himlen betyder, at gudbilledlighedens negative ytringer i mennesket som savn og længsel, drøm og minde ikke bliver dækkende for Jesu liv, til gengæld bliver de positive ytringer som kærlighed og sandhed så meget mere fremtrædende. I forbindelse med opvækkelsen af enkesønnen fra Nain taler Grundtvig om, at Jesus kommer med 
sin Faders kærlighed (II 79). Samme kærlighed møder vi i skikkelse af sorg, hvor Jesus græder over det faldne menneskes skæbne forud for opvækkelsen af Lazarus og ved indtoget i Jerusalem (III 218 og V 339). Men frem for alt træder Jesu lighed med Gud frem,når han taler. Når Jesus taler, hører folk i hans ord Gud selv tale, eller i det mindste burde de gøre det, for det er skabende gudsord, Jesus taler (II 75). At Jesus taler Guds ord rejser igen spørgsmålet, om Gud da så virkeligt er blevet menneske? Er det ikke snarere sådan, at Jesu menneskelighed blot er et hylster Gud benytter til at gøre sit ord hørt i verden ved? Grundtvig mener nej. I et langt digt i første bind af Sangværket redegør han for sammenhængen mellem Guds skaberord, menneskeordet og Jesu ord (I 81): Guds ord er almægtigt og er forudsætningen for alt, der er til. Følgelig skylder alt eksisterende dette skaberord sin eksistens. Men ligesom Gud afbilder sig selv i mennesket, har han også ladet sit ord spejle sig i menneskets tale, og han låner ydermere dette menneske noget af sin egen skaberevne, så mennesket kan udtrykke, hvad der gør indtryk på det; den kraft der i mennesket betinger, at det kan skabe en sproglig virkelighed af, hvad det føler og tænker, er Guds egen And, som han ved skabelsen indblæste mennesket. Gudsordet og menneskeordet er altså ikke fremmede for hinanden, og Gud har da også gennem menneskets historie gentagne gange brugt menneskeordet til at tale igennem (str. 19, jvf. også IV 394). Vel er det altså noget nyt, der sker, da Guds ord bliver menneske og lyder fra et menneske, men der er hverken tale om, at guddommeligheden eller menneskeligheden ophæves, for selve menneskeordets væsen og beskaffenhed er inkarnationens mulighed. Og dog mener Grundtvig - i al fald i I 81, at der ved inkarnationen sker en overanstrengelse af menneskeligheden:

"Ny Vin de gamle Kar,

Og overspændte Strænge

Sig selv, maa snarlig sprænge,

Stor-Ordet derfor længe

I Støvets Mund ei var!" 
I talen udtrykker den talende sig selv. Og fantastisk er det jo, at et menneske kan gøre alt det, der rumsterer i dets egen krop og hjerne til noget, det kan dele med andre i kraft af sproget:

\section{"Min Sjæl, du har af alt paa Jord \\ I Tanken og din Tunges Ord \\ De allerbedste Vinger."}

I talen flyver vi rundt mellem hverandre og hæver os endda i bøn og lovsang til den himmel, vi aldrig har set, men kun aner.

I sit ord udtrykker også Gud sig selv. Og selv om inkarnationen, da ordet blev kød var en overanstrengelse af menneskelivet, så enheden af Gud og menneske i Jesus ikke blev den varige tilstand, disciplene havde troet, så skete det dog som et mægtigt vidnesbyrd om, hvad det er Gud vil: at jord og himmel skal forenes, at Gud og menneske skal blive ét. Derfor kalder Grundtvig også i I 81 Jesu levetid for jordens bryllupsdage, et billede, vi skal vende tilbage til senere.

Jeg har i det nærmest foregående hæftet mig særligt ved Jesu ord som Guds ord. Det er ikke tilfældigt, for det gør Grundtvig også. Men det skal dog med, at Grundtvig er helt klar over, at ordet bliver $k \phi d$ i Jesus fra Nazareth. Ordet og kødet er i Jesus uadskilleligt forbundne, derfor fortier Grundtvig heller ikke, at Gud udtrykker sig selv ikke blot i, hvad Jesus siger, men i hvad han gør i det hele taget og i hvad han er (se f.eks. V 125).

Inkarnationen er vidnesbyrdet om, at Gud og menneske kan blive ét. Men hvad hjælper det, når mennesket, bortset fra Jesus, er faldet og det vil sige besat af en magt, der bestandig skiller det fra Gud ved at lade mennesket tvivle om Gud og blive bange for ham, sådan som Simon viser det i "Der sad en Fisker" (II 74). Syndens magt, der skiller mennesker fra Gud må overvindes. Det sker, foreløbigt og relativt, hver gang Jesus knytter mennesker til sig, og det sker hver gang Jesus med sit ord bryder gennem den død og forstening, syndens magt medfører, idet død for Grundtvig er udtryk for den endelige adskillelse fra Gud. Denne gennembrydelse af dødens barrierer udfolder Jesus, når han kalder døde til live, helbreder syge og trøster sørgende, og det fremgår ydermere af salmerne, at han også gennembryder den adskillelse, der søges fremkaldt med hans egen død, se f.eks. salmen "Guds 
Ord blev aldrig bundet", hvor Jesu ord, selv da han tages til fange og dør har magt til at trøste den bodfærdige røver på korset.

Jesu livs betydning for mennesket sammenfatter Grundtvig i ordparret: frelser og broder. I disse to ord ligger alt det, vi hidtil har draget frem. Jesus er vor bror, for han er menneske som vi. Og han er vor frelser, for $i$ ham udfolder Gud sin magt $i$ hele dens rækkevidde. Men i understregningen af at Jesus er bror og frelser gennem hele sit liv ligger også en omplacering af det, man i klassisk kristologi henfører til Jesu død: forsoningen, udslettelsen af fjendskabet mellem menneske og Gud. På en måde sker forsoningen hos Grundtvig, da Maria undfanger Jesus, da begynder jordens bryllupsdage. Det svarer ganske godt til dette forhold, at det element i kristologien, hvortil udslettelsen af fjendskabet mellem Gud og menneske traditionelt henlægges, nemlig Jesu lidelse og død, hos Grundtvig får en forholdsvis beskeden plads $\mathrm{i}$ salmerne. Jeg tror, at grunden til at der tales så lidt om Jesu død er, at her gør Jesus, hvad der ikke kan tales om. I døden træder han helt uden for den erfaringsverden, hvorfra menneskesproget henter sit materiale. Når Grundtvig så alligevel skildrer hvad der foregår i dødsriget, tiest med fælleskristelige billeder hentet fra jura og krigskunst, er det vel at mærke ikke Jesu død han skildrer, men hans opstandelse. Det er sejren over døden. Men forud for Jesu sejr over døden gik at han led døden. Hvad det vil sige at lide døden, kan der ikke tales om, for der går al menneskelig tales grænse. I døden går Jesus alene, som vi alle skulle gøre det, hvis ikke han var død og opstanden for os og med os. Og som vi kun kan se hverandres død udefra, kan vi også kun se Jesu død udefra:

"Soel-Formørkelsen den fulde

Med al Vinter-Nattens Kulde

Den blev seet ved Middagstid,

Da i Dødens Vold hengivet, Han, som Lyset er og Livet, Streed for os den gode Striid 
Med ham døde paa en Maade

Selv Guds Sandhed og Guds Naade,

$\varnothing$ de var da Jorderig,

Løgnen jubled, Avind haaned.

Troen vakled, Haabet daaned,

Kiærlighed var bleg som Lig!" (V 85.1f).

I øvrigt er der en tendens til, at Grundtvig henlægger fornedrelsens bund til dødsangstscenen i Gethsemane, sådan at Jesu oplevelse af døden og adskillelsen fra Gud sker her, hvor vi kun kan sove, mens han strider for os (V 203.7).

Betydningen af Jesu død, som der altså ikke tales særligt entydigt om, er at der banes vej for os gennem døden ud af døden. Efter himmelfarten er Jesus kød i himlen, så ligesom der ved inkarnationen banes vej fra himmel til jord, ja helt ind $\mathrm{i}$ døden, banes der ved opstandelse og himmelfart vej fra døden og fra jorden til himlen.

Større teologisk betydning end himmelfarten har dog for Grundtvig opstandelsen, og opstandelsessalmen frem for nogen er vel nok I 302: "Tag det sorte Kors fra Graven". Essensen i denne salme er at Jesus fortsætter sit værk i kraft af Guds ord at bryde gennem dødens ødelæggelse og forstening. Det sker i mødet med den sønderknuste Maria Magdalene, hvis sorg i første omgang brydes ved forkyndelsen af Herrens opstandelse for så, da han taler til hende som frelseren, at forsvinde $\mathrm{i}$ lys.

Menneskets ulykke er adskillelsen fra Gud, derfor er menneskets lykke, at Gud kommer til det og taler til det som dets broder og frelser, og det bliver lykke over lykke, at Gud udspænder sit komme til at omfatte ikke bare én menneskegeneration, men alle tidligere og kommende generationer. Det første, Guds komme til de tidligere generationer skildres i Kædmon-gendigtningen "I Kvæld blev der banket" i mødet mellem urmoderen Eva og hendes og skaberens efterkommer: Jesus. Helt tilbage til det første faldne menneske er Jesus her trængt, og han tager hende til sig og rejser hende, menneskemoderen uden et ord! men med et kys, som vel på én gang skal danne modbillede til Judaskysset og foregribe kærlighedskysset ved Gudssønnens og menneskemenighedens bryllup. I salmen "Tag det sorte Kors fra Graven" slår scenen med Maria, der møder den opstandne Jesus 
ved graven direkte over $\mathrm{i}$ en opstandelsesproklamation med udgangspunkt i vor situation: Guddomsmanden er her, hvert hans ord er liv og ånd, bod vi fik for alle savn.

Det har alle dage stået kristne klart, at Jesu opstandelse måtte betyde, at han på en eller anden måde kan være til stede, hvor han vil, uhindret af de grænser, der sættes af rum, tid og død. Men i kraft af sin kirkelige anskuelse og den dermed sammenhørende tro på, at Jesus er til stede i sine egne ord, der lyder ved dåb og nadver, kan Grundtvig tale mere konkret og entydigt om den opstandne herres nærvær, end det ellers sker: Ligesom Faderen udtrykker sig selv i sit ord, og dermed også i Jesus, da ordet bliver kød, sådan udtrykker Jesus også sig selv i de ord, han taler.

I Dannevirke-tiden er Grundtvig nået frem til en forståelse af fænomenerne "ord" og "sprog", der går ud på, at ord kan ses som trefoldige størrelser, hvor lyden, den levende bestemte tanke og ånden virker sammen, idet de to sidste begreber svarer til, hvad vi ville kalde ordets indhold og dets overbevisningskraft. Ordet er altså udtryk for, at det private, individet selv, kan udbrede sig og møde andre uden for sig selv takket være noget legemligt, lyden, og noget usansbart, men opleveligt, nemlig den virkende, personlige kraft, ånden. Når et menneske dør, eller et menneskeligt fællesskab går til grunde, kan det ikke længere formidle sig selv. Grundtvig forstår dette i lyset af skabelsesberetningen. Når mennesker kan træde ud over de grænser, rummet sætter for dem - og for særligt fremragende individer også tiden -, skyldes det ånden, som Gud blæste ind i det nyskabte menneske (I 81.12f, $15 f)$.

Jesu opstandelse viser sig (hvordan den skal forstås er som Jesu død skjult) ved at Jesus på ny ligesom før han døde træder ud af sig selv $i$ sine ord og er levende og overbevisende til stede hos dem, han taler med. Og som han var det før han døde, er han også som den opstandne den, der stiller menneskehjertets længsler og savn. Han er den, der udfolder kærlighed, og han er den der frelser. Vi så det lige før i "Tag det sorte Kors fra Graven", hvor Jesus for den sorglammede Maria gennembryder sin egen død og er levende til stede ved hendes side som vennen, der siger: her er frelseren, Marie.

Ligeledes ser vi det flot skildret i Grundtvigs sang om de to, der 
påskedag gik til Emmaus (II 89), hvordan Jesus "med Ild i Bryst" river de to triste, gamle og knarvorne disciple ud af deres mismod, får deres øjne til at skinne og deres hjerter til at brænde, indtil det omsider, da han bryder brødet for dem, går op for dem, at det er Jesus selv, der taler til dem.

De to ovenstående eksempler viser, henlagt til tiden umiddelbart efter Jesu opstandelse det centrale og allermest væsentlige $i$ Grundtvigs forståelse af Kristus: alt det, der i NT fortælles om Jesus, finder sin forklarelse i, hvad Grundtvig selv oplever i sit eget møde med Gudsordet. I "Tag det sorte Kors" har vi proklamationen "Ja, Han er her, Guddoms-Manden,..." og i II 89 har vi efter 36 strofers gengivelse af Emmausvandringen en opfordring til menigheden om at lukke ørerne op og høre Kristi fredlysning, for $\mathrm{i}$ den er han opstanden for os, og der henvises til, at den opstandnes nærvær "fornemmes" ved nadveren. For Grundtvig er det vigtigste $\mathrm{i}$ forbindelse med Kristus at få sagt, at det samme uformidlede møde med Gud, som var en mulighed, da Jesus levede i Palæstina, og som blev realitet for nogle den gang, det er fra og med Jesu opstandelse og Helligåndens udgydelse en mulighed for alle, og det bliver stadig realitet for nogle. Kriteriet for at dette er sandt, er for Grundtvig, at de virkninger, det den gang havde, at ordet blev kød, gør sig gældende i dag, som det samme ords tilsvarende virkninger. Det vil, som vi har set, sige, at syndefaldet overvindes, at Gud kommer nær og at det, der skiller os fra Gud overvindes, nemlig synd og død, så Jesus er til stede hos os som den, der på én gang er Faderens ord og vores broder og frelser. At dette virkeligt sker, er påstanden i Grundtvigs udsagn om Kristus. Ikke billedligt og ikke som troens produkt, men direkte, levende og virkelig, hævder Grundtvig, at Jesus er til stede i dag i samme forstand som et menneske, der taler til et andet, er til stede og virker ind på det. Det er et forhold Grundtvig tager op den ene gang efter den anden: kun hvis virkningerne af Jesu frelsesgerninger gør sig mærkbart og føleligt gældende hos os, så vi erfarer, at det er vores frelse, det drejer sig om, er Jesus også vores frelser. Således hedder det i IV 280: 
"Hvad engang til Mænd og Kvinder

Han har talt om Liv og Fred,

Det ei os med ham forbinder,

Kommer os slet ikke ved,

Uden os et Ord han sender

Og med Flid til os henvender,

Som for os er Liv og Aand."

Ja, Grundtvig insisterer i så høj grad på, at er Kristus verdens frelser, da må han også være til stede som frelser her og nu, at han lader hele kristentroen stå og falde med, at mødet med Kristus er en nutidig begivenhed af samme art og virkelighed som al menneskelig tale:

"Lyslevende, vor Herre, du

Sad ei paa Ærens Sæde,

Hvis ei du var hos os endnu

Lyslevende til Stede;

Thi var dit Ord til os kun Tant,

Da var dit Guddomsliv ei sandt,

Da var du kun en Praler" (IV 170).

Den Kristus, som har mødt os i det ord, han har talt til os, kan vi derefter møde i Biblens beskrivelse af ham (I 34.17).

Det er kendt for alle, at Grundtvig identificerer de ord, hvori Kristus formidler sig til menigheden med de ord, der lyder ved dåb og nadver. Imidlertid viser en salme som "At sige Verden ret Farvel" (IV 95), at sagens kerne ikke er den ydre formelle identitet mellem ord talt af den historiske Jesus og de ord, vi på vor side hører som Jesu ord til os. Det afgørende er, at det er Jesus, Guds søn og Marias søn, frelseren og broderen, vi hører tale til os, og det kan i denne salme ske uden om sakramentsordene gennem en nær vens ord. For det, det for Grundtvig dybest set drejer sig om, er Guds nærhed. Men den vigtigste måde for Grundtvig at udtrykke denne nærhed på blev at udnytte hans egne overvejelser over sprogets væsen teologisk og at forbinde disse overvejelser med sakramentsordene i deres egenskab af Kristus-ord. Derved nåede Grundtvig frem til at kunne pege på 
det konkrete sted for Guds nærvær i Jesus Kristus i hans og den kristne menigheds egen samtid, og det var ved dåb og nadver $i$ ordene af Herrens egen mund. For så vidt etablerer Grundtvig en ny objektivitet $\mathrm{i}$ kristendommen. Han giver den troende kristne et sted og en tid, hvor han kan møde genstanden for sin tro, nemlig hvor og når ordene lyder ved dåb og nadver. Man kan sige, at han befrier den troende fra den byrde at skulle hive sig selv op ved hårene ved hjælp af troen. Grundtvig bliver imidlertid ikke stående ved denne sakramentsobjektivitet. Den står derimod i tæt forbindelse med en ny subjektivitet: Kristus lader det ikke være nok med at formidle sig selv til troen i sine ord ved dåb og nadver, men han lader sig genføde og vokser i den enkelte troende som herlighedens håb og derigennem også $\mathrm{i}$ fællesskabet af troende, der udgør det gudsfolk, der er Herrens legeme. Den stadige samvirken mellem det objektive, ordet, og den subjektive følelse fremgår af IV 5 "Vor Herre! til Dig maa jeg tye," hvor bolværket mod trosfjendernes spot er den trøst, hjertet føler, når det påkalder Kristus, og bevidstheden om at han er i det hellige ord, han selv har lagt menigheden i munden og hjertet. De to led hører sammen. Uden ordet er troen blind (I 23) og flakker forvildet omkring kun for at knytte sig til den første den bedste autoritet, som den blodsottige kvinde, der i sin elendighed har prøvet mange læger, inden hun hører om Jesus og hos ham finder helbredelse (I 12 og II 76). Den blinde tro er identisk med hjertets gudbilledlighed hos det faldne menneske, genlydsordet, der er revet løs fra det ord, det er genlyd af. Hvordan troen og den blinde tro forholder sig til hinanden får man et levende billede af ved at sammenligne de to paralleldigte "Der sidder en Dronning paa Gyldenskrin" (IV 28) og "Der sidder en Enke paa GyldenSkrin" (III 158). Når den blinde tro ved dåben med sin døde søn, det sværmende håb, møder Kristus, da genfødes håbet som håb om herlighed. Det samme handler I 137 "Jeg veed et lille Himmerig" om: salmens to første strofer skildrer stedet hvor menigheden samles om dåb og nadver som et lille himmerig, for der er Jesus selv til stede (str.3-5). Str. 6-11 skildrer kirken som Bethlehem, grænsebyen til Guds rige, hvor den nye Adam, der skal stige til himlen, er født. Derpå hedder det: 
"Vi fandt Ham svøbt, i Krybbe lagt,

Foruden og forinden,

Og gjorde med den Lille Pagt

Mod Døden og mod Fjenden!".

Dette at menigheden finder den lille "foruden og forinden" udtrykker dobbeltheden mellem Kristus uden for os, i ordet, og inden $\mathrm{i}$ os, $\mathrm{i}$ håbet. $\mathrm{Om}$ dette håb handler resten af salmen, der fra strofe 14-21 skildrer hvordan det spæde håb i den troende ved at høre om Jesu gerninger genkender sin egen livsbane og lover at gentage Jesu gerninger $\mathrm{i}$ den døbte, når det er vokset op til jæuning med ham.

Kristus lever og vokser $\mathrm{i}$ den døbte som håbet om herlighed. Selve udtrykket har Grundtvig hentet i Kolossenserbrevet kap.1 vers 27. Chr. Thodberg har i bogen "En glemt dimension i Grundtvigs salmer" (Kbh. 1969) påvist, hvordan herlighedshåbet har sit udtryk i fadervor. Så mens Kristus uden for os kommer til os i trosbekendelsens ord i deres spørgende form, ytrer han sig inden i os i sin egen barnebøn til Gud Fader. I håbet, der vokser i fasthed og sikkerhed indtil det til sidst opløses i væren, og i barnebønnens ord, der stiger fra jord til himmel, fuldbyrder Jesus i sine døbte den himmelfart, han for sit eget private vedkommende udførte 40 dage efter sin opstandelse (jvf. III 152.9 og IV 258). Den væren, håbet til slut skal opfyldes og opløses $\mathrm{i}$, er kærlighed, læser vi i IV 258, og da Grundtvig med Johannesskrifterne fremhæver, at Gud er kærlighed, kan tanken om håbet der opfyldes i kærligheden ses som en udfoldelse af 1. Kor 15.28, hvor Sønnen Kristus, til slut underlægger sig Faderen, for at Faderen kan være alt $i$ alle.

Vi har set, at der i følge Grundtvig sker noget nyt med os ved dåben: der fødes et håb $\mathrm{i}$ os, et håb, der dybest set er Jesus selv, som altså har det samme uforstyrrede, tillidsbårne barneforhold til Gud, som Jesus ene af alle havde og kunne have, fordi den magt, der skiller os andre fra Gud hverken er en illusion eller en misforståelse, men en realitet, en ond magt, der driver os til at vende os mod intetheden i stedet for at vende os mod Gud, der er al virkeligheds ophav. Og som Jesus voksede i en verden, der var i splid med sig selv, vokser håbet $\mathrm{i}$ os, som en ny sikkerhed og 
fasthed, midt i det kaos, som menneskelivet også er. Men dåben er ikke blot en begivenhed, der vedrører os og vort private forhold til Kristus. Ved dåben genfødes vi ind $i$ en ny sammenhæng: Paradisets og evighedens sammenhæng, der omfatter levende og døde samt de himmelske væsner, som det fremgår af 1850-udgaven af "Sov sødt Barnlille" (IV 193), den sammenhæng, som er den kristne menighed.

Nadveren relaterer sig til begge de nævnte aspekter af dåben: Kristi fødsel i os som Herlighedens Håb, og vores genfødsel ind i menighedens sammenhæng. Og ligesom Grundtvigs dåbsudsagn bliver kristologiske udsagn, fordi de handler om, hvad Kristus gør, således kommer også nadveren til at handle om, hvad Kristus gør. Når det er sådan, skyldes det, at Grundtvig i så høj grad fokuserer på ordene ved dåb og nadver og opfatter disse ord som den skikkelse, hvori Kristus er levende og handlende til stede hos os.

Ved nadveren rækker Kristus os i sit ord til os sit kød og blod. Går man salmerne igennem, er det påfaldende, hvor ofte Jesu kød og blod ved nadveren associeres med Eden:

"Paradisets Vin og Brød

Styrker os i Liv og Død"

synger vi i II 131, og med en storslået samlæsning af Genesis, Salme 80, Jesaja og Johannesevangeliet hedder det i V 163:
"Livs-Vintræet fra Guds-Haven
Bar en Drue Himmelsød
Spildt paa Korset og i Graven
Synes Saften purpurrød,
Men i Herrens Mindes-Baeger
Evig dog den vederkvæger!"

Meningen må være, at Kristus med det ord, hvormed han giver den troende sit legeme og blod, skænker den fra syndens magt befriede legemlighed. For at forstå rækkevidden af dette er det vigtigt at vide, at Grundtvig nogle steder kan bestemme synden som udtryk for det forhold, at kødet vil være ånd. Det er et stærkt billedligt udtryk for menneskets besættelse af tanken om sin egen autonomi 
"Thi Skaber-Had og Djævelskhed Er Kiødets Sands til Døden"

hedder det i III 212. I samme salme skildres, hvordan himmellængslen i mennesket havde været redningsløst fortabt, hvis ikke Gud havde befriet den ud af det greb, kødsansen holder den i; men det er netop det, Gud gør i sit ord ved dåb og nadver, som i Helligåndens kraft trænger ind i den døbte og som Åndens sans kæmper mod kødsansen. Det er betegnende, at denne kamp, som til syvende og sidst er en kamp mellem Kristus og Satan skildres i en terminologi, der er som hentet ud af påskesalmen "I Dødens Baand":

"Det er en Kamp paa Liv og Død, Ja, Kamp imellem Begge"

(nemlig mellem liv og død), men som i påskesalmen ender det hele godt med livets og åndens sejr:

"Saa bygges atter op i Løn,

Om Nætter og om Dage,

Den gamle Kongebolig skiøn

Som har paa Jord ei mage!"

Det er den gamle bolig, der bygges op, det er Paradisets vin og brød der nydes, det er den oprindelige, ufaldne legemlighed, der rækkes mennesket, det er Kristi legemlighed, så sandt han, som vi tidligere så, kom til os som et menneske af kød og blod, over hvilket synden ingen magt havde. I den forstand er nadveren det sted, hvor befrielsen af mennesket fuldbyrdes. Men samtidig med at nadveren er det sted, hvor Kristus over for det onde vinder en af sine afgørende sejre, er den også det sted, hvor han i positiv forstand udfører Guds frelsesforehavende ved at formidle Guds kærlighed til mennesket og lade den udbrede sig mellem mennesker. I Nyaars-Morgen har Grundtvig skabt et smukt billede af alterkalken, der vælter og strømmer ud over jorden for derfra atter at strømme ind i Himlen (Forspillet til Sang-Værk I str. 3031). Atter er det nyttigt for forståelsen at gribe til en påskesalme 
for at uddybe billedet, for kalken, der strømmer ud over jorden og ind i Himlen, det er jo selve den flod der synges om i "Hil dig, Frelser og Forsoner" (I 232), nemlig Jesu blod, der vælter sten og smelter isbjerge, den flod der strømmer gennem hans ord ind i de troende og knytter hjerterne til hverandre og til Gud. Med andre billeder siges helt det samme IV 233 "Jesus, at du blev min Broder". Salmen tager udgangspunkt i troens forundring over inkarnationen og Jesu stedfortrædende død som et himmelsk kærlighedsvidunder. Men hvordan skal den troende forholde sig over for denne kærlighed? Svaret er, at kun den kærlighed, Jesus skænker den troende er stærk nok til at møde den kærlighed, Jesus har vist ham, dette fuldbyrdes ved nadveren, hvor Jesus med ordet giver sit $k \varnothing d$ og blod i stedet for synderens af kødsansen besatte $k \varnothing d$ og blod:

"Ja, dit Ord, hvormed du giver

Mig dit eget Kiød og Blod

I mig var og er og bliver

Livets Træ med Livets Flod

Alle Aandens Frugter maa

Skabes for din Skyld derpaa,

I dem alle som i Eden

Voxer, modnes Kiærligheden!"

Når opdagelserne af sprogets natur og muligheder begejstrede Grundtvig sådan, var det fordi, han så sproget som det medium, der bryder den menneskelige isolation $\mathrm{i}$ individer og skaber mulighed for menneskeligt fællesskab i gensidig samvirken. Men for at sproget skal kunne binde mennesker sammen i hjerteligt fællesskab, kræves der også noget mere, der kræves at de samtalende er båret og behersket af Gud Faders eget væsen, af kærligheden. Som vi har set, opfatter Grundtvig verden som behersket af netop den magt, der får mennesket til at vende sig bort fra Gud. Derfor er troen, der som disposition er den overleverede gudbilledlighed $\mathrm{i}$ mennesket, og håbet, der er den bevidsthed om hvad der venter den enkelte, som udspringer ved mødet mellem ordet og troen, ikke nok til en genrejsning af det faldne menneske. Genrejst bliver dette menneske først, idet Kristi gudhengivne menneskelighed tager skikkelse i det og det sker, når 
troen ved ordet ser håbet styrkes og bekræftes, fordi enheden med Kristi kød og blod er udtryk for en endnu stærkere sammensmeltning med Kristus, end troen og håbet tidligere har kendt, og fordi den enhed med Kristi kød og blod, der er en realitet for troen, hvor den tager imod Kristi ord ved nadveren, betegner sammenbruddet for den "Kiødets Sands" der har som sit eneste mål at skille mennesket fra Gud.

Den sammensmeltning, hvor Kristus og den troende bliver ét kød kommer for Grundtvig som for andre, til at betegne en dybere opfyldelse af forjættelsen til de to køn i Genesis 2 (IV 273), en opfyldelse, der igen peger frem mod den endelige, når Kristus ved tidernes ende kommer synligt fra himlen for at hente sin brud hjem (V 280).

Jeg hævdede indledningsvist, at jeg ville prøve at sammenfatte de udsagn om Kristus, jeg har fundet hos Grundtvig i hans salmer, til en sammenhængende skildring af, hvordan Gud i Jesus Kristus griber ind for at føre det faldne menneske tilbage i den livgivende vekselvirkning med Gud, hvori det alene kan vokse og forklares til den guddomsherlighed, hvortil det blev skabt. Vi har i det foregående set, at en sådan skildring kommer til at tage sit udgangspunkt i bevægelsen fra himmel til jord ved bebudelsen, en bebudelse, der gentages, hver gang ordet finder troen og godtages af den. Skildringen fortsætter med, at det inkarnerede gudsord lever et menneskeliv, som i forhold til det faldne menneskeliv er på én gang nyt og gammelt, nyt fordi det udfoldes $\mathrm{i}$ den forbundethed med Gud, der er det faldne menneske fremmed, gammelt, fordi det er dén menneskelighed, der er menneskets oprindelige, som det på én gang har mistet og bevaret erindringen om.

Vi så, at den egentlige befrielseshandling for mennesket, overvindelsen af døden, finder sted uden for det menneskelige erfaringsområde, hvorfor den kun kan beskrives gennem dens resultat, opstandelsen, eller udefra, som en negation af alt værende. Det viste sig, at alt dette finder sted med det formål at føre mennesket tilbage til den fortrolighed og forbundethed med Gud, hvori det skal vokse til lighed med ham. Denne bevægelse aftegnes foregribende i Jesu himmelfart, og finder sted, idet Jesus Kristus vokser i de troende døbte som håbet om herlighed, og idet mennesket ved nadveren $\mathrm{i}$ troens modtagelse af ordet får den 
nyskabte legemlighed, der var Jesu menneskelighed, hvori kødets sans med dens had til Gud ingen magt har. Således bliver nadveren på én gang den begivenhed, hvor mennesket i menigheden begynder det liv i kærlighedsfællesskab med Gud og næsten, som er det sande menneskeliv, samtidig med at den som foreløbig forening af Kristus og menigheden peger frem mod det eskatologiske bryllup mellem Gud og menneske, himmel og jord.

Hos Grundtvig selv er der tilløb til sådanne sammenfatninger $\mathrm{i}$ "Kirkelige Oplysninger 1840-42", i Den christelige Børnelærdom og i de forskellige kirkehistoriske overblik, men generelt må man sige, at hans frygt for at sammenblande timelig skolesag med evig salighedssag nøder ham til at færdes med "stor Forsigtighed og Ydmyghed" på dette område.

Når jeg desuagtet vover at trodse al forsigtighed og ydmyghed for at behandle dét skolemæssigt, som egentlig kun kan opleves, skyldes det den teologiske situation, vi i dag står i, hvor kristendommen åndshistorisk i stadig højere grad fremstår som et afgørende, men nu passeret, led i den proces, der har ført til tilværelsens sækularisering og menneskets autonomi. I denne situtation finder jeg det af afgørende vigtighed at fremdrage den sammenhængende lære om Kristus, jeg finder ligger bag alle Grundtvigs enkeltudsagn om Kristus, fordi denne bagvedliggende kristologi, hvor det primære ikke er det afsluttede og overståede, men det vordende og aktuelt skeende, repræsenterer en påstand om, at samspillet mellem Gud og menneske ikke sluttede, da disciplene måbende så Guds Ord forsvinde i himmelblået, hvorefter de og menneskeheden var henvist til at stå på egne ben, men at tværtimod Guds Ord lever og handler i de gudsord, der lyder og høres i verden nu. 